\title{
Experimental Study on Mechanical Property of Stiffening-ribbed-hollow- pipe Reinforced Concrete Girderless Floor with Four Clamped Edges Supported
}

\author{
Weijun Yang ${ }^{*}$, Yongda Yang, Jihua Yin, and Yushuang Ni \\ Changsha University of Science and Technology, Changsha, Hunan, 410114, China
}

\begin{abstract}
In order to study the basic mechanical property of cast-in-place stiffening-ribbed-hollow-pipe reinforced concrete girderless floor, and similarities and differences of the structural performance compared with traditional floor, we carried out the destructive stage loading test on the short-term load test of floor model with four clamped edges supported in large scale, and conducted the long-term static load test. Also, the thesis conducted finite element analysis in virtue of ANSYS software for solid slab floor, stiffening-ribbed-hollow-pipe floor and tubular floor. The experiment indicates that the developing process of cracks, distribution and failure mode in stiffening-ribbed-hollow-pipe floor are similar to that of solid girderless floor, and that this kind of floor has higher bearing capacity and better plastic deformation capacity. The finite element analysis manifests that, compared with solid slab floor, the deadweight of stiffening-ribbed-hollow-pipe floor decreases on greater level while deformation increases little, and that compared with tubular floor, this floor has higher rigidity. So stiffening-ribbed-hollow-pipe reinforced concrete girderless floor is particularly suitable for long-span and large-bay building structure.
\end{abstract}

Keywords: stiffening ribbed hollow pipe; reinforced concrete girderless floor; mechanical property; experiment study; finite element analysis (FEA).

\section{INTRODUCTION}

The earliest cast-in-place reinforced concrete hollow girderless floor can originate from Germany, proposed by MULLER Leopold firstly, an engineer of former Federal Republic of Germany [1]. Later, HENDLER Edgar, American engineer, also put forward a cellular girderless floor, a kind of hollow girderless floor that put the block foamed plastics as the filling components. It has a big hollow ratio [2]. At abroad, the hollow girderless floor is generally divided into two kinds: one is Voided Flat Plate, which has a small hollow ratio, and most of which is tube -shaped cavity; another is Cellular Flat Plate, which has a big hollow ratio, and is Rectangular cavity mostly [4].

In recent years, the tubular hollow girderless floor has been adopted in many projects in China, which put the thin-walled cement tubes as the filling components. Furthermore, China also has carried out some experimental investigation and theoretical research [3-5], which has made a lot of achievements on the research of deformation property, mechanical property and analytical methods of such floor. Since such kind of floor has particularity of orthotropy in structure, its structural performance needs some further in-depth study. Reference [3] employed the newly-developed stiffening ribbed hollow pipes recently as the filling

*Address correspondence to this author at the Changsha University of Science and Technology, Changsha, Hunan, 410114, China;

Tel: +86-73185258197; Fax:+86-731-85258197; E-mail: mgbyrh@163.com components, and carried out the experimental investigation of the mechanical property, load spread and difference between bearing capacity and rigidity in both forward-tube and perpendicular-to-tube directions of the tubular hollow girderless floor under the condition of uni-axial bending. Stiffening-ribbed-hollow-pipe cast-in place reinforced concrete girderless floor is a new-style reinforced concrete hollow floor system (shown in Fig. 1). In this kind of floor, the stiffening-ribbed hollow pipes are placed as pore-forming internal mold so that the floor becomes hollow structure. The stiffening-ribbed hollow pipe is a kind of newly-developed chemical building material. It is made in proportion from macromolecular gelatinization material, special fibre, sand, water and blending agent etc. And its external shape is like a pipe (shown in Fig. 2). It is called stiffening-ribbed hollow pipe in this paper since there is a stiffening rib in the hollow pipe. And the cast-in place reinforced concrete girderless floor in which the stiffening-ribbed hollow pipes are placed as internal mold is called stiffening-ribbed-hollow-pipe cast-in-place reinforced concrete girderless floor (called stiffening-ribbed-pipe girderless floor for short in the following text).

On such basis, this paper conducted a floor model test in a large scale, 1:2 to investigate the bidirectional mechanical property of stiffening-ribbed-hollow-pipe girderless floor with four clamped edges supported [6], and carried out the long-term load test to figure down its security under the effect 


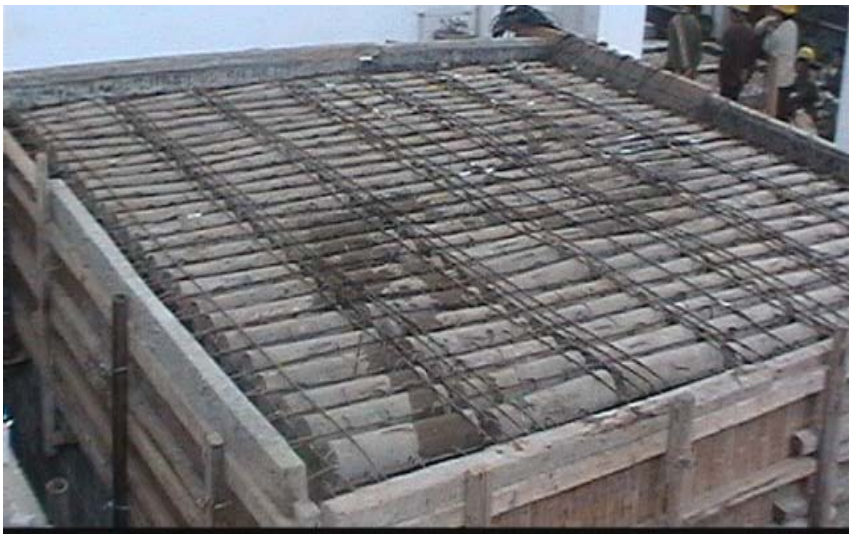

Fig. (1). Stiffening-ribbed-pipe girderless floor.

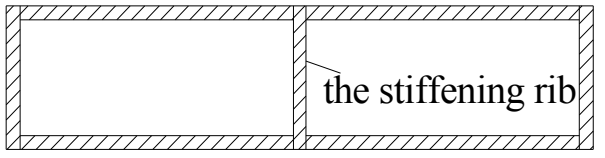

vertical section

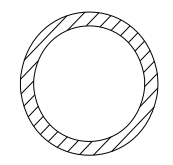

cross section
Fig. (2). Stiffening ribbed hollow pipe.

of long-term load. it provides the reliable and essential measured data for the design and popularization of such floor.

\section{INTRODUCTION OF THE EXPERIMENT}

\subsection{Test Objective and Specimen Making}

The static test of the angular point fixed two-way slab measured the stress, strain, deflection and crack distribution under different class of loading, and also, determined the ultimate bearing capacity of such kinds of floor. The failure characteristic was observed in this process.

The plane size of the test model of stiffening-ribbedhollow-pipe girderless floor with four clamped edges supported is $4000 \mathrm{~mm} \times 4000 \mathrm{~mm}$; its thickness is $160 \mathrm{~mm}$. The filling material is stiffening ribbed hollow pipe with the diameter of $100 \mathrm{~mm}$, length of $470 \mathrm{~mm}$ and thickness of pipe wall about $5 \mathrm{~mm}$. The hollow ratio of this floor is $30.53 \%$. The structural layout of stiffening ribbed hollow pipe in such girderless floor is as follows: the space in the vertical direction is $30 \mathrm{~mm}$; in parallel direction is $35 \mathrm{~mm}$; the distance from upper surface is $25 \mathrm{~mm}$, and the same from the lower surface. Fig. (3) is the structural layout diagram of such girderless floor. The whole floor employs $\Phi 6$ reinforcing steel bar; Fig. (4) is the diagram of reinforcing bars. In order to imitate the support conditions of four clamped edges, deep beam with height of $450 \mathrm{~mm}$ and width of $240 \mathrm{~mm}$ is adopted around the floor as a fixup. The vertical equally distributed load is exerted to the floor to test the distribution of the internal force, cracks in structure, deformation, bearing capacity, and of such floor under the condition of being supported by four clamped edges, as well as the influence of anisotropy on its bearing capacity and rigidity.

\subsection{Test Methods}

The test adopts bricks and weights to load simultaneously. Each brick weighs $24 \mathrm{~kg}$ (average value of ten bricks in random sampling). Bricks and weights are piled up on the floor to imitate the uniform load. If the loading materials are stacked on the surface of the structure directly, the loading materials themselves will be caused arch camber, which can bring about unloading effect for the structure [7,8]. As a consequence, the loading adopts the form of $4 \times 4$ brick piers with $133 \mathrm{~mm}$ distance among piers. Fig. (5) shows the concrete form. The deflection value is measured by dial test indicator. After centering adjustment at measuring point, the dial indicators are fixed on the steel tubes of the supporting frame through magnet stand. To facilitate the process of deflection value, initial reading of the dial indicator is set to zero before test. The dial indicators measuring girder sedimentation are placed above the floor, the rest of which are fixed below the floor. The positions of dial indicators are illustrated in Fig. (6). Readings are recorded on different degree of load grade. On the basis of the analysis of deflection change, it indicates the carrying capacity and rigidity of the floor at each stage of elastic plasticity. As illustrated in Fig. (7and 8), strain foil of steel and concrete is set at following points on the surface of

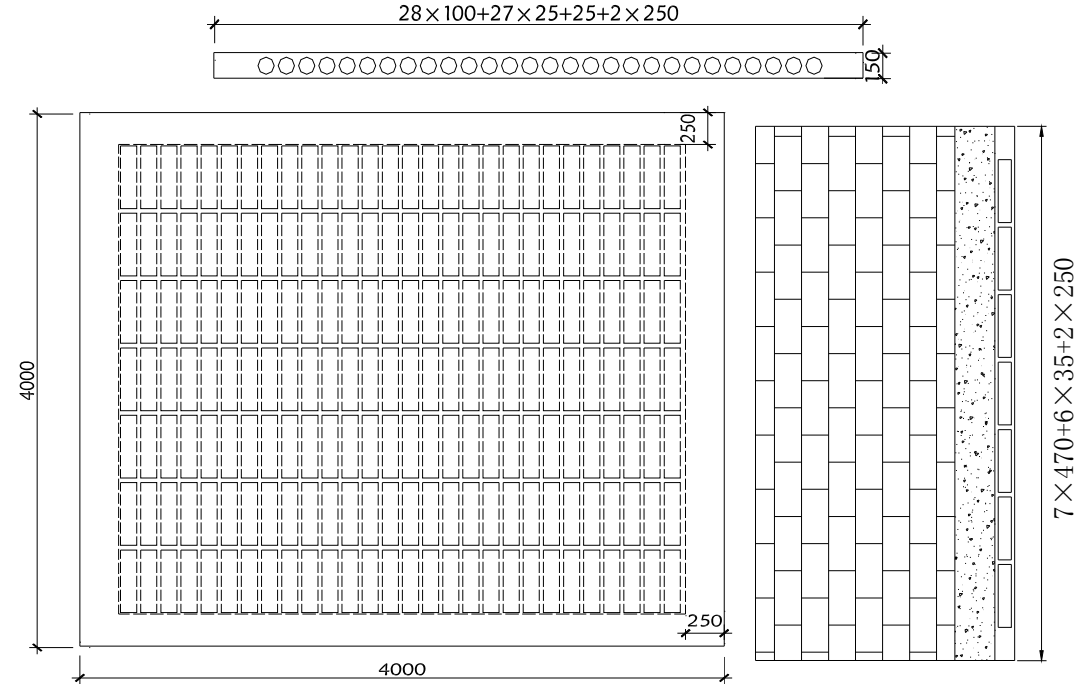

Fig. (3). The structural layout diagram of stiffening-ribbed-pipe girderless floor. 

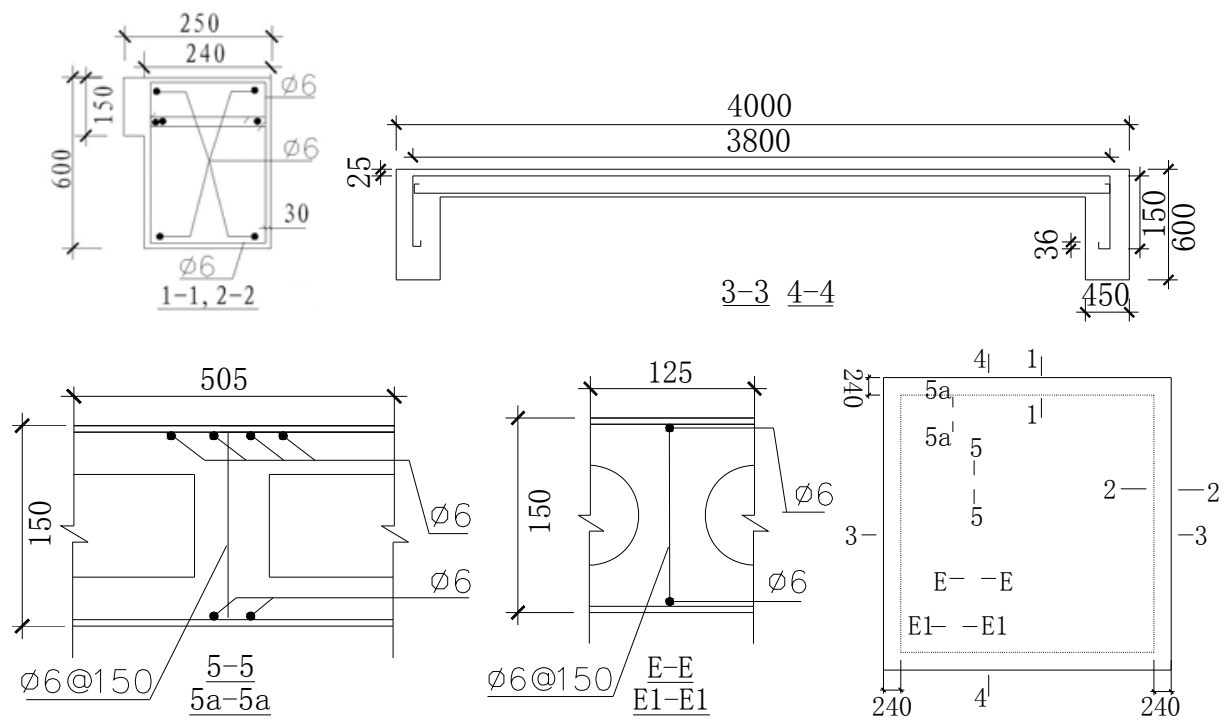

Fig. (4). Diagram of reinforcing bars of stiffening-ribbed-pipe girderless floor.

Table 1. List of Stepped Load

\begin{tabular}{|c|c|c|c|c|c|c|c|c|c|c|}
\hline Stepwise Loading & $\begin{array}{c}\text { First Stage } \\
1\end{array}$ & \multicolumn{7}{|c|}{ second stage } & \multicolumn{2}{|c|}{ Third Stage } \\
\hline accumulative total load $\left(\mathrm{kN} / \mathrm{m}^{2}\right)$ & 2.731 & 9.731 & 15.856 & 20.141 & 24.426 & 27.489 & 32.289 & 34.164 & 35.164 & 36.164 \\
\hline
\end{tabular}

steel and concrete inside the floor. The influence of temperature is eliminated through public compensation method. The strain data of steel and concrete on different degree of load grade is collected by data acquisition unit (7V14c) so as to analyze their strain change of floor from elastic stage to plastic stage. There exists a static duration of 15 20 min after each loading. The crack developing state of components will not be observed until deformation and cracks of the floor become stable. Meanwhile, record the deflection value and strain.

The load program is shown as follows: the first phase of loading is increased to $2.731 \mathrm{kN} / \mathrm{m}^{2}$ to reach the design values of the constant load; then step into the second phrase, the secondary increment is $7.200 \mathrm{kN} / \mathrm{m}^{2}$; the third level increment is $6.125 \mathrm{kN} / \mathrm{m}^{2}$, the fourth and fifth level $4.286 \mathrm{kN} / \mathrm{m}^{2}$; the sixth level $3.063 \mathrm{kN} / \mathrm{m}^{2}$, the seventh level $4.800 \mathrm{kN} / \mathrm{m}^{2}$, and the eighth level $1.875 \mathrm{kN} / \mathrm{m}^{2}$. The third phrase put the increment of $1 \mathrm{kN} / \mathrm{m}^{2}$ to conduct gradation loading till structural damage. The test load is carried out after 60 days when

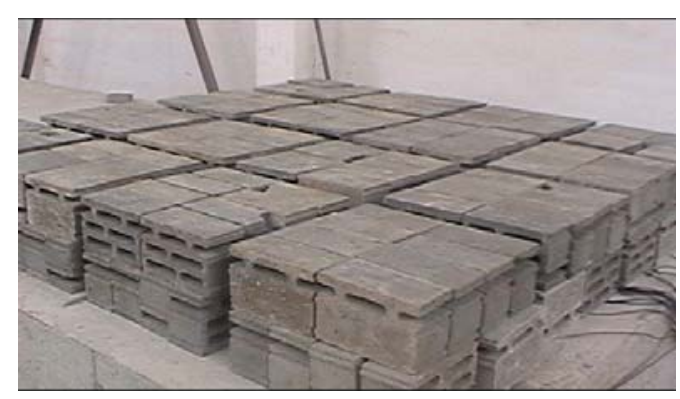

Fig. (5). Loading mode of the test floor. concrete pouring is finished. The stepped load program is presented in Table $\mathbf{1}$.

\section{EXPERIMENTAL PHENOMENA AND ANALYSIS OF SHORT-TERM STATIC TEST}

3.1. Cracks and Failure Mode of Stiffening-ribbed- hollow-pipe Girderless Floor

The Stress and strain increase with the load of floor. Until the third load of $23.26 \mathrm{kN} / \mathrm{m}^{2}$, some slender along-pipe cracks appear at the bottom of the floor (Fig. 9). To the fourth level of $27.5 \mathrm{kN} / \mathrm{m}^{2}$, many places show insequent short cracks, and present diagonal development trend (Fig. 10). Meanwhile, cracks appear simultaneously at the place from the wall about

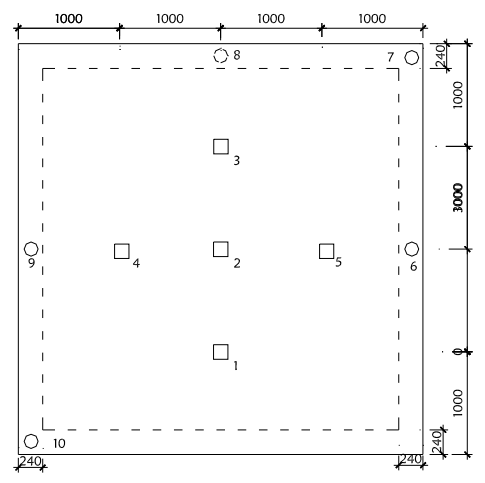

$\square$ under the floor $\bigcirc$ on the floor

Fig. (6). Position of dial test indicator. 


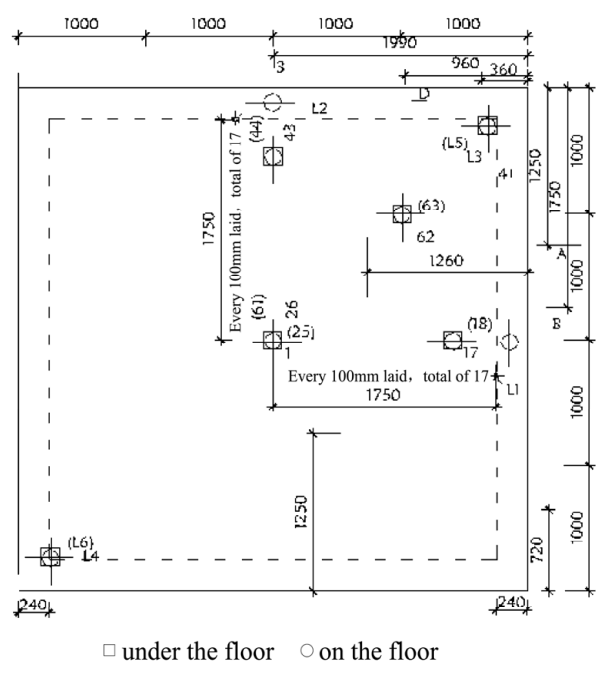

Fig. (7). Layout of concrete strain gauge.
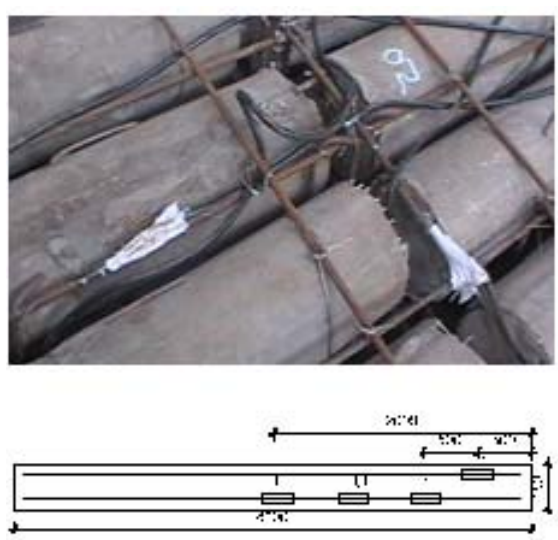

$\square$ under the floor $\bigcirc$ on the floor

Fig. (8). Layout of reinforced strain gauge.

$100 \mathrm{~mm}$ in both along-pipe direction and vertical-pipe direction of the floor surface. With the seventh grade load of $38.32 \mathrm{kN} / \mathrm{m}^{2}$, there is no torsional moment plane on the diagonal of the floor because of symmetry. The diagonal plane is primary moment one, so the primary moment is perpendicular to the diagonal, the bottom of floor splits along the $45^{\circ}$ direction bilaterally. The cracks along the diagonal direction widen unceasingly and their length stretches to four corners (Fig. 11). Simultaneously, the original cracks develop continually, part of along-pipe cracks run through with each other, with maximum crack wide to $0.31 \mathrm{~mm}$. Cracks at the crossing section present the crisscrossed trend, and form cracking area like turtleback. Under the eighth load of $41.76 \mathrm{kN} / \mathrm{m}^{2}$, cracks along the diagonals become wider and develop to four corners; vertical and horizontal cracks at the crossing section are about $2 \mathrm{~m}$, and furthermore, new cracks appear along the diagonal and vertical-horizontal directions (Fig. 12). At this time, the maximum crack width is $0.35 \mathrm{~mm}$. With the ninth load of $44.01 \mathrm{kN} / \mathrm{m}^{2}$, cracks along the diagonal at the bottom of the floor split rapidly, and others also become wider and longer. Till the tenth load of $46 \mathrm{kN} / \mathrm{m}^{2}$, new cracks still appear at the bottom, crossing-section, diagonal direction and 1/4-span of the floor, and distribute densely and fockedly.
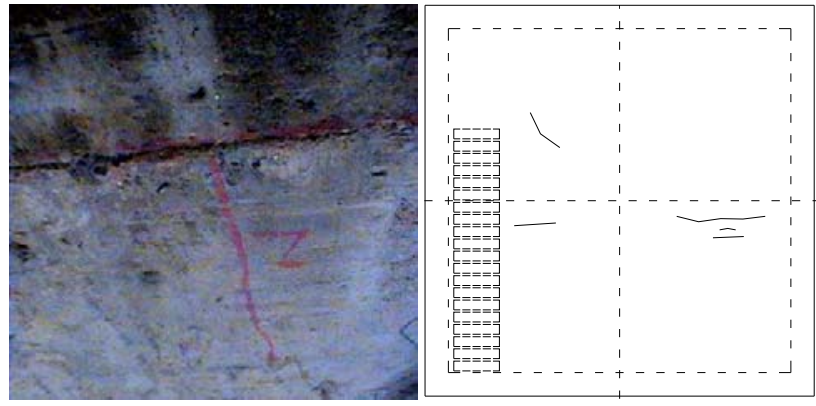

Fig. (9). Cracks under third load.

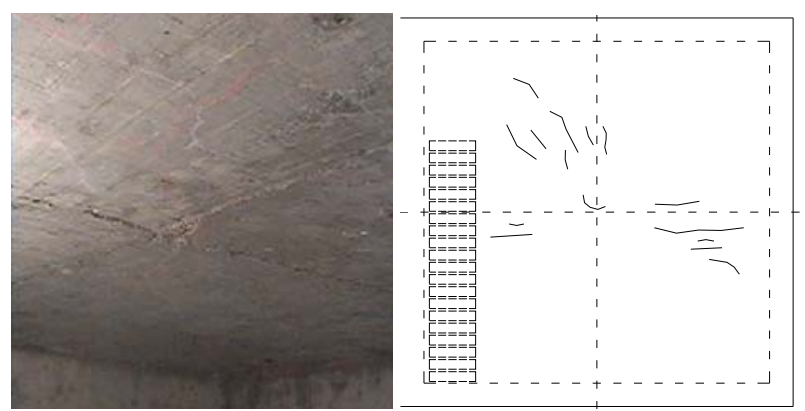

Fig. (10). Cracks fourth load.
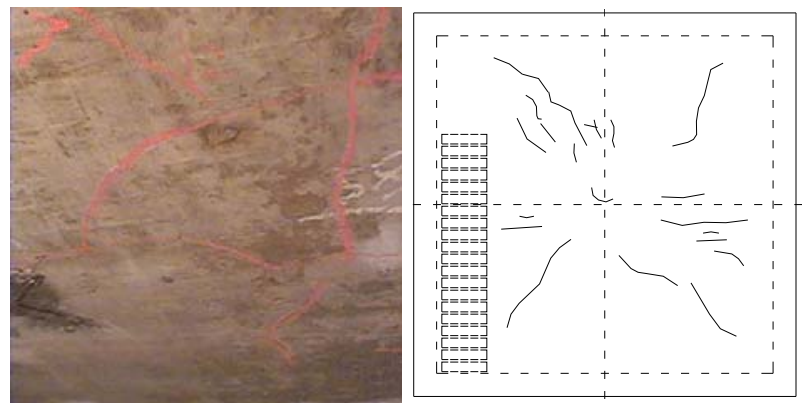

Fig. (11). Cracks under seventh load.

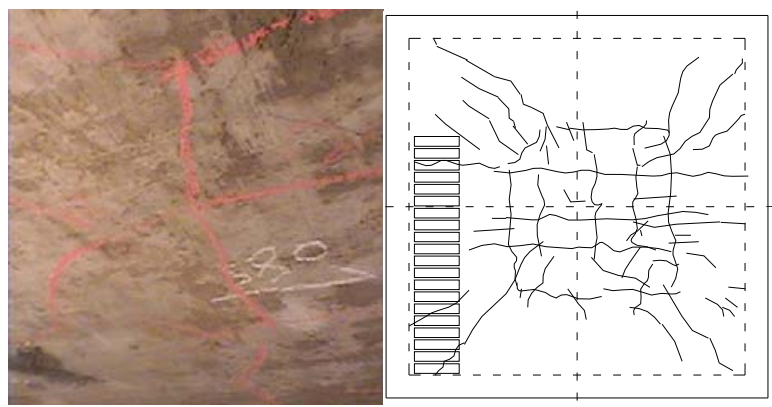

Fig. (12). Cracks under eighth load.

For the eleventh load of $46.10 \mathrm{kN} / \mathrm{m}^{2}$, cracks at the bottom of the floor grow much longer and wider, whose maximum width reaches to $0.93 \mathrm{~mm}$. The floor is destroyed completely with a twelfth load.

The testing results of cracks indicate as follows: (1) cracks of the floor at service stage mainly concentrate at the crossing section of the bottom, but they develop very slowly. Therefore, the rigidity of the floor declines unobviously. While these cracks reach to $0.31 \mathrm{~mm}$, the maximum deflection is $4.09 \mathrm{~mm}$ at the crossing-section, which far from the permissible value of $18.75 \mathrm{~mm}(1 / 200)$ provided in the specifications. 
As a consequence, at the normal service stage, the floor is mainly controlled by the width of cracks. (2) During the failure stage, at the crossing-section, the main vertical and horizontal cracks along curb girder orthogonally and those along two orthogonal diagonals develop rapidly, and grow much wider. So at the failure stage, the floor is also mastered by the width.

\subsection{Stress Deforming Analysis of the Stiffen- ing-ribbed-hollow-pipe Girderless Floor}

Fig. (13) is the load-deflection curves at the midspan of the floor, 1/4-spans in parallel-to-pipe direction and vertical-to-pipe direction. Because of orthotropy of the floor, bending rigidity of the section paralleled to the pipe is different from that in vertical direction, and the rigidity in vertical direction is less than that in parallel direction, which is manifested obviously through the curved surface of the deflection distribution. With the same load, the deflection paralleled to the pipe is less than that in the vertical direction at the same spans.

\subsection{Strain Distribution of the Reinforcing Steel Bar and Concrete}

The analysis of strain data of the reinforcing steel bar demonstrates the following points: (1) the mechanical property of the test floor is the same with that of the solid floor fundamentally. The largest reinforcement strain appears at the crossing-section of the wall; those at the crossing-section take second place; the strain at the $1 / 8$ is the smallest. The flexural moment at the crossing-section of the wall is the largest, and

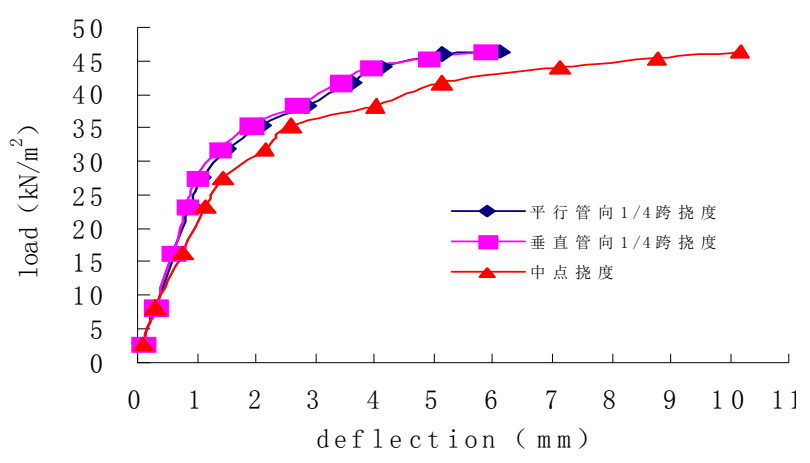

Fig. (13). Load-deflection curve of the floor.

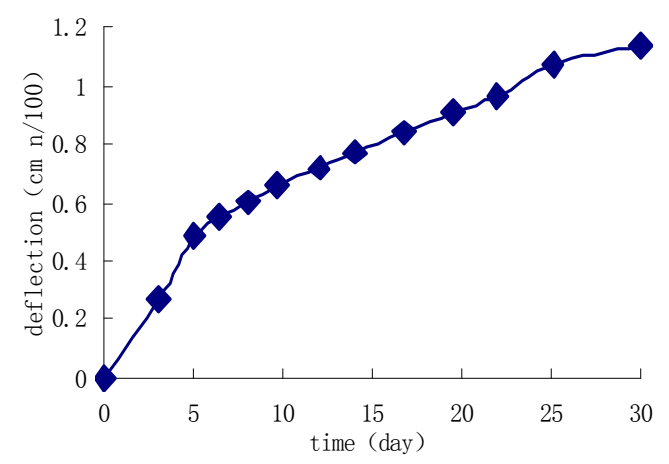

Fig. (14). Long-term deflection chart of the test floor. generally transforms into hogging moment to the edges of the floor. (2) Stress on the reinforcing steel bar in the paralleled direction is above and beyond that in the vertical direction, which is identical to that section rigidity paralleled to the pipe is larger than that in the vertical direction. (3) While close to failure, reinforcement strain at the crossing-section increase rapidly, and distribution reinforcement becomes tension from press, which indicates that neutral axis goes up, and the floor will be destroyed.

The strain data of the concrete indicate as follows: (1) when the load reaches to $27.5 \mathrm{kN} / \mathrm{m}^{2}$, the concrete strain gauges close to one end of the wall at the crossing-section in vertical direction of the floor surface spill out; to $31.75 \mathrm{kN} / \mathrm{m}^{2}$, the concrete strain gauges at the other end of the wall also brim out, which illustrates that at this time, the end wall of the floor has already presented cracks under the effect of the negative bending moments. The cracks come into being at the place from floor end about $250 \mathrm{~mm}$, shown as Fig. (12). (2)

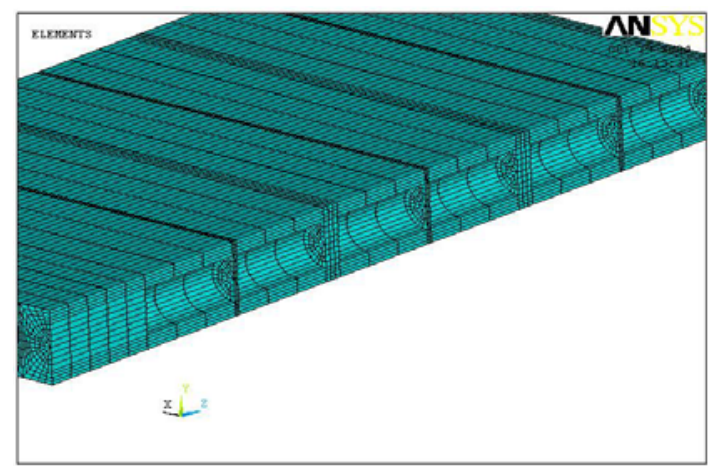

Fig. (15). The stiffening ribbed floor.

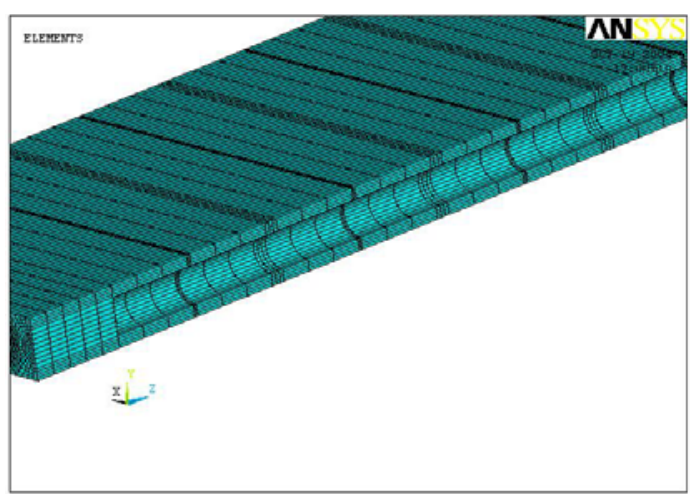

Fig. (16). The tubular floor.

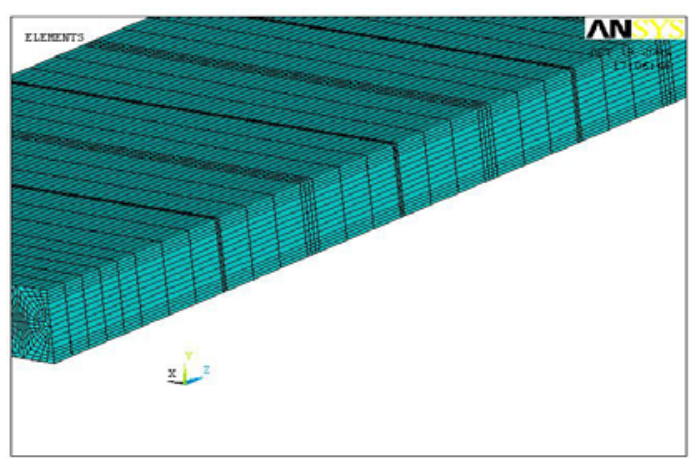

Fig. (17). The solid floor. 
Except that the strain values of the wall ends are positive values, other strain values of the measuring points on the floor surface along the diagonal are all negative values before $41.76 \mathrm{kN} / \mathrm{m}^{2}$, and in which two measuring points at the crossing-section shows the smallest negative value, which matches up to the theoretical analysis. Strain values at the measuring points at the wall ends are all positive values, but all of them are lea than those of crossing-section measuring points, which indicates that the direction of maximum stress is perpendicular to the wall body. (3) The strain values at all measuring points show that concrete of the floor surface and floor side bears pulling force, and concrete in other area receives pressure. (4) The strain values at the crossing section along the diagonal direction are less than those at other measuring points obviously, which illustrates that, at the crossing section, the orientation of principal stress extends along the wall body. This is in accordance with the cracking phenomenon.

\section{RESULTS OF THE LONG-TERM LOADING TEST}

After exerting the load, we spent a month measuring the change of deflection under the uniform load of $14 \mathrm{kN} / \mathrm{m}^{2}$. According to the one-month observation, the deflection of the floor, under the effect of the 1.48 times the standard load $\left(9.46 \mathrm{kN} / \mathrm{m}^{2}\right)$, develops rapidly in five days after load, and later, the changing value of the deflection is very small, and generally decreases as the increasing of time. Fig. (14) shows the change curve of the load with the time. In the whole observation process, the deformation of the stiffening-ribbed-hollow-pipe girderless floor is just $1.137 / 100 \mathrm{~cm}$, which proves that the whole floor is safe under the effect of long-term load.

\section{FINITE ELEMENT ANALYSIS OF THE STIFFEN- ING-RIBBED-HOLLOW-PIPE GIRDERLESS FLOOR}

\subsection{Finite Element Model}

In virtue of ANSYS software, the finite element model of the stiffening-ribbed-hollow-pipe girderless floor, which is identical to the test model from aspects of structure and size, is established to carry out the finite element analysis in order to shape a compression with the test results. Meanwhile, to compensate for the trial deficiencies caused by limited conditions, solid floor model and tubular floor model, both of which has the same support conditions and external dimensions, are also set up to shape a contrast with stiffeningribbed-hollow-pipe girderless floors so as to obtain a deep knowledge of mechanical properties of the stiffening-ribbedhollow-pipe girderless floors.

The plane size of the finite element model is $4.0 \mathrm{~m} \times 4.0 \mathrm{~m}$ (including the solid hidden beam at the end); and this model adopts square plate with slab thickness $160 \mathrm{~mm}$; the rib spacing is $35 \mathrm{~mm}$; pore diameter $100 \mathrm{~mm}$. The solid floor model is established by the way of stuffing the hollow part of the stiffening-ribbed-hollow-pipe girderless floor with concrete units, and the tubular floor model is the model that all pipes in the stiffening-ribbed-hollow-pipe girderless floor become once-through pipes without cast-in-place concrete separating pipes among. The element type and mesh generation of the tubular floor and solid floor are same as the stiff-

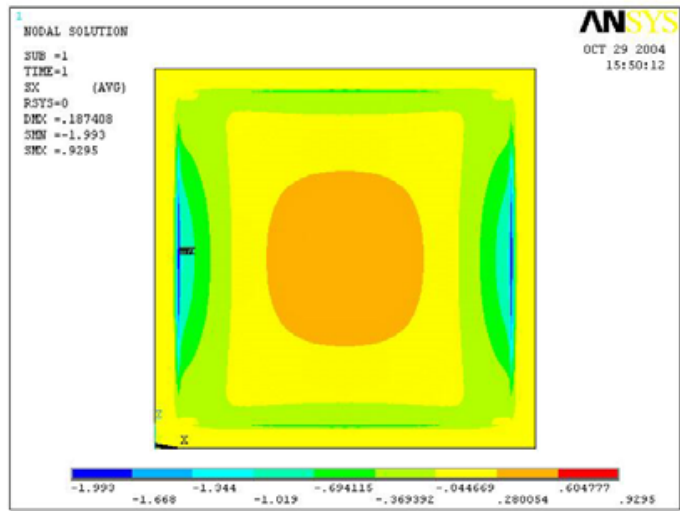

Fig. (18). Bottom $\sigma_{\mathrm{x}}$ nephpgram of solid floor

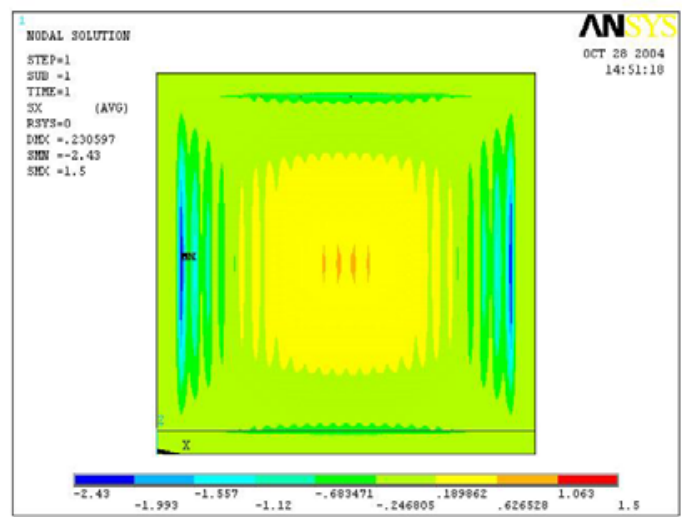

Fig. (19). Bottom $\sigma_{x}$ nephpgram of tubular floor

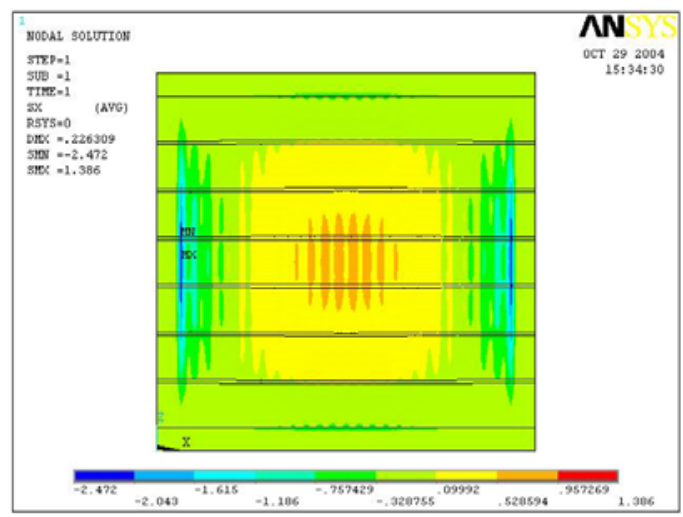

Fig. (20). Bottom $\sigma_{\mathrm{x}}$ nephpgram of stiffening ribbed floor

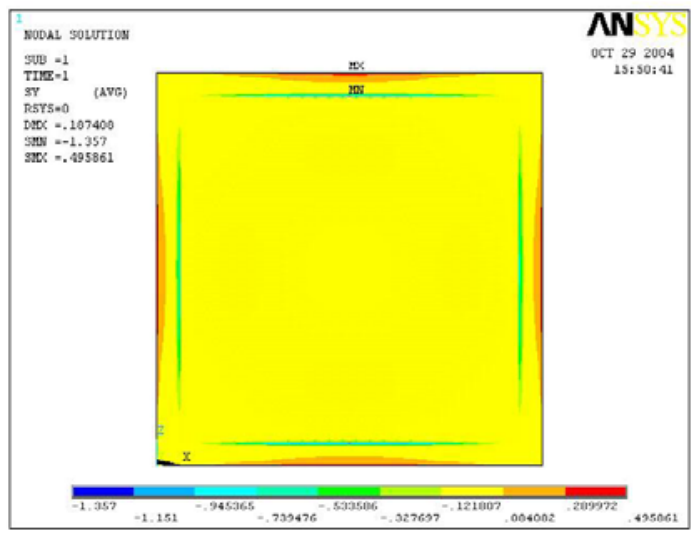

Fig. (21). Bottom $\sigma_{\mathrm{y}}$ nephpgram of solid floor 
ening ribbed floor, in order to facilitate the succeeding stress analysis, shown as Fig. (15-17). The element type adopts the 8-node isoparametric element, SOLID45, and the planar four-node isoparametric element, PLANE42 with elasticity modulus $\mathrm{EX}=\mathrm{EY}=\mathrm{EZ}=2.8 \times 10^{10} \mathrm{~Pa}$, Poisson's ratio $\mu=0.2$. The load takes $8.15 \mathrm{KN} / \mathrm{m}^{2}$. To facilitate the description, it is commonly promised that the floor surface is $x-y$ geometric plane, and the direction of plate thickness is $\mathrm{Z}$-axis direction. In view of the comparability of the model, the models are exerted the load at the same level without consideration of the distinction of their dead load.

\subsection{Results of Finite Element Analysis}

\subsubsection{Stress Analysis}

In order to form a visual and rough comprehension on a whole for the stress performance of various slabs, the following figures show their stress nephpgrams under the same load (Fig. 18-20).

From Fig. (18-20), the distribution of X-direction stress at the bottom-slab of the stiffening ribbed floor is between solid floor and tubular floor, larger than that of solid floor and less than that of tubular floor. The distribution of stiffening ribbed floor, $\sigma \mathrm{x}$, along the direction of Slab $\mathrm{X}$ and $\mathrm{Z}$ is much smoother, compared with the solid floor. The distribution of $\sigma x$ ranging $0.045-0.280 \mathrm{~N} / \mathrm{m}^{2}$ presents ellipse in the nephpgram, but circular among $0.529-0.957 \mathrm{~N} / \mathrm{m}^{2}$. The stress distribution trend of the stiffening ribbed floor in X-direction is roughly the same with that of the tubular floor. Merely, the nephpgram range of the second largest stress of the tubular floor at the central area is smaller than that of the stiffening ribbed floor.

From Fig. (21-23), it is clear that except for the difference on the maximum stress (MS), the stress distribution nephpgrams of these three floors in Y-direction shows the same range basically, and the stress in $\mathrm{Y}$ direction is less than those in other two directions.

From Fig. (24-26), the distribution of Z-direction stress at the bottom-slab of the stiffening ribbed floor is between solid floor and tubular floor, larger than that of solid floor and less than that of tubular floor, with the smallest distributed area among these three floors. However, the second largest stress distributed area of the stiffening ribbed floor is slightly larger than that of tubular floor. Both stiffening ribbed floor and tubular floor present indented concavo convex at the edge of the first and the second stress distribution areas, it is causesd by embedded tube causes.

\subsubsection{Deflection Analysis}

Without considering dead load, Table 2 shows the deflection contrast values of the solid floor, stiffening ribbed girderless floor and tubular floor under the external load of $8.15 \mathrm{kN} / \mathrm{m}^{2}$.

As can be seen from Table 2, compared with tubular floor, deflection of stiffening ribbed girderless floor declines by $2 \%$ in the case of a small increase of dead load, which indicates that this structural style has good rigidity. Compared with solid floor, dead load of stiffening ribbed girderless floor decreases sharply while its deflection just increases by $20 \%$.
Therefore, such structure form has obvious advantages in the project.

\section{CONCLUSION}

After integrating the experimental study with the finite element analysis, the following conclusions can be obtained about the stiffening-ribbed-hollow-pipe girderless floor:

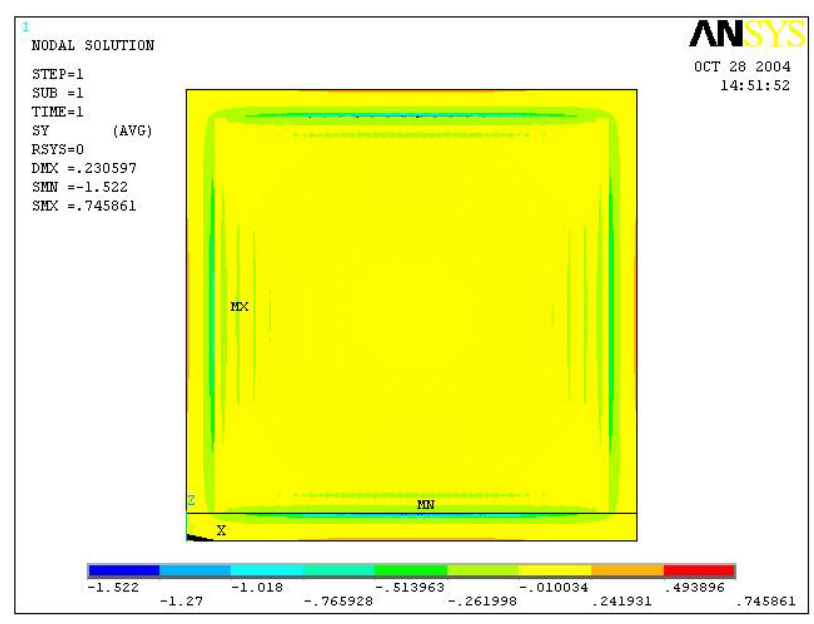

Fig. (22). Bottom $\sigma_{\mathrm{y}}$ nephpgram of tubular floor

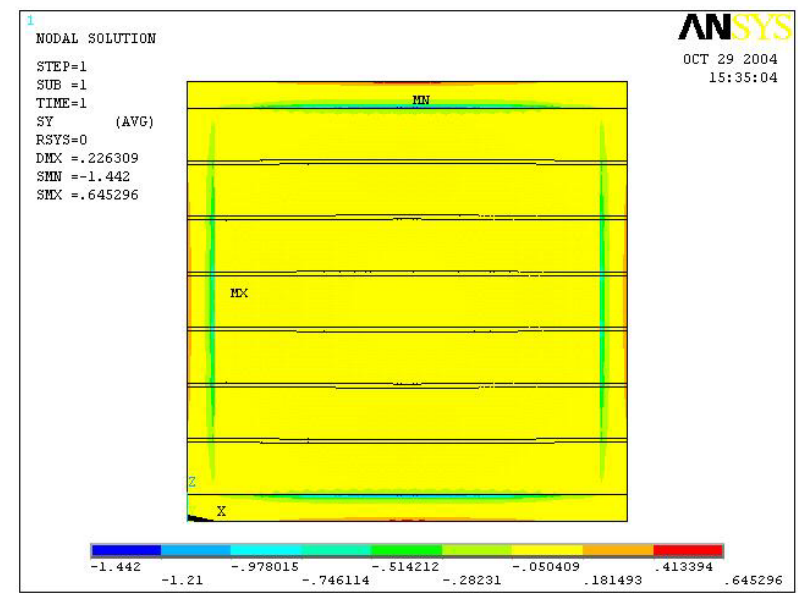

Fig. (23). Bottom $\sigma_{y}$ nephpgram of stiffening ribbed floor

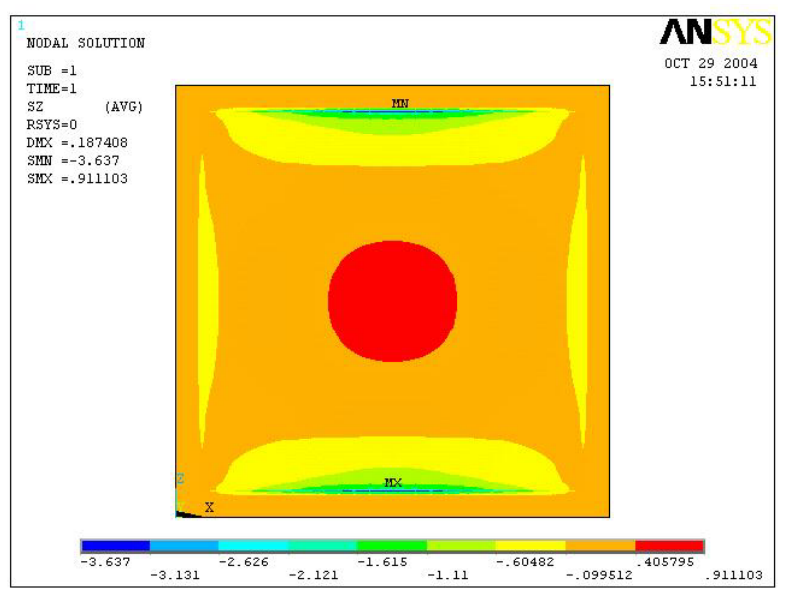

Fig. (24). Bottom $\sigma_{z}$ nephpgram of solid floor 
Table 2. Deflection Values Not Comparison Considering Dead Load

\begin{tabular}{|c|c|c|}
\hline Types & Maximum Deflection Value $(\mathrm{mm})$ & Ratio \\
\hline \hline the solid floor $\left(8.15 \mathrm{kN} / \mathrm{m}^{2}\right)$ & 0.187 & 1.000 \\
\hline stiffening ribbed girderless floor $\left(8.15 \mathrm{kN} / \mathrm{m}^{2}\right)$ & 0.226 & 1.209 \\
\hline the tubular floor $\left(8.15 \mathrm{kN} / \mathrm{m}^{2}\right)$ & 0.231 & 1.235 \\
\hline
\end{tabular}

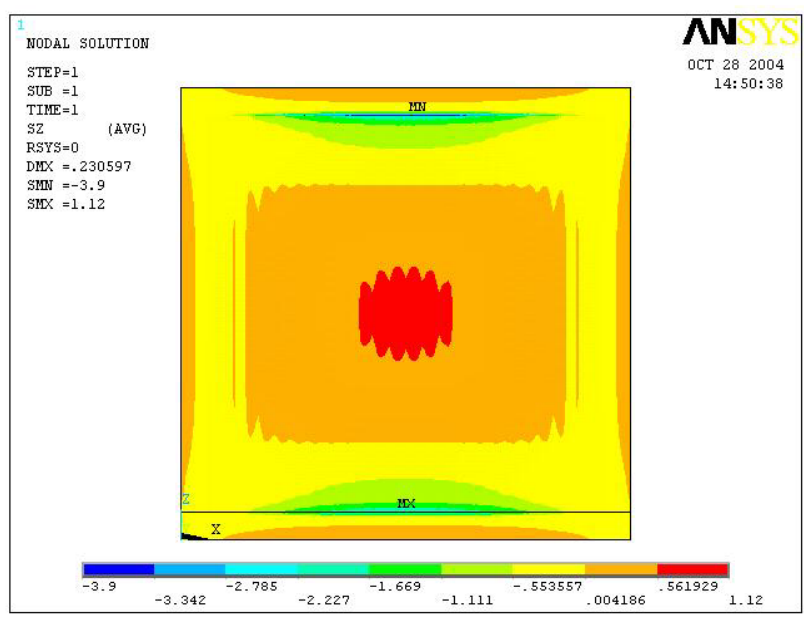

Fig. (25). Bottom $\sigma_{z}$ nephpgram of tubular floor.

1. The mechanical property of stiffening-ribbed-hollow-pipe girderless floor with four clamped edges supported is the same with that of the solid floor fundamentally, and its distribution of the internal force and stress deforming developing process are similar to those of the solid floor. However, both regular service and failure of such floor are mainly controlled by the width of main cracks.

2. Stress on the reinforcing steel bar in the paralleled direction is far above and beyond that in the vertical direction; the cross-section deflection paralleled to the pipe is less than that in the vertical direction at the same spans. These phenomena illustrates that the cross-section bending rigidity paralleled to pipe is larger than that in vertical direction. The strain data of concrete shows that the direction of maximum stress is perpendicular to the wall body; at the crossing section, the orientation of principal stress extends along the wall body, which is in accordance with the cracking phenomenon.

3. Through the long-term loading test, the deflection of the floor increases most rapidly at the initial period of load. Deflection within 5 days accounts for $30 \%$ of the combined deflection approximately; in the ensuing 21 days, the changing value of deflection becomes placid; and the deflection of last four days only occupies about $4 \%$ of the combined deflection, which can be regarded as a constant. The test manifests that the entire floor is safe under the long-term load, and can satisfy the The normal operating requirements of structures completely.

4. Compared with tubular floor, deflection of stiffening ribbed girderless floor declines by $2 \%$ in the case of a small increase of dead load, which indicates that this structural style has good rigidity. In comparison with solid

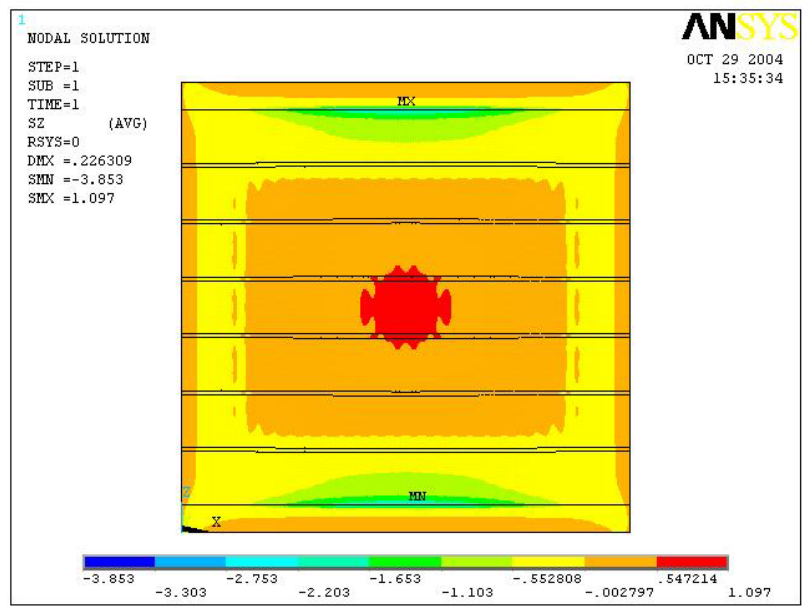

Fig. (26). Bottom $\sigma_{z}$ nephpgram of stiffening ribbed floor.

floor, dead load of stiffening ribbed girderless floor decreases sharply while its deflection just increases by $20 \%$. Therefore, such structure form has obvious advantages in the project.

5. The stiffening-ribbed-hollow-pipe girderless floor is a floor system with light dead load and high rigidity. As a result, it is particularly suit for large-span and large-bay building structures. And such floor structure has a wide application prospect in the architectural engineering.

\section{CONFLICT OF INTEREST}

The author(s) confirm that this article content has no conflicts of interest.

\section{ACKNOWLEDGEMENT}

None declared.

\section{REFERENCES}

[1] G. Elliot and L. A. Clark. "Circular Voided Slab Stiffness", Journal of the Structural Division, ASCE, vol. 108, no. ST11, pp. 2379-2393, 1982.

[2] Z-X. Gao and W-R. Cheng, "The Design and Construction of the Multi-cell Flat Plate Floor Using Thin Wall Boxes", Special Structures, vol. 19, no. 2, pp. 45-48, 2002.

[3] W-J. Yang, X-B. Yu, Z-H. Zhang, Z-Y Qiu, C-W Liu and J-H Yin. "Experimental study on simply supported slab of reinforced concrete stiffening ribbed hollow pipe girderless floor". Journal of Changsha University of Science and Technology(Natural Science), vol. 4, no. 2, pp. 21-26, 2007. (In Chinese)

[4] W. Cheng, H. Jiang, Z. Gao, X. Z. Huang, J. P. Wu and S. B. Li, "Experimental study of tubular voided flat plate floor". Journal of Building Structures, vol. 25, no. 5, pp. 78-84, 2004. (In Chinese) 
[5] Quan Xueyou, Sun Huilang and Wang Wei, "Experimental study on mechanical properties of one-way model slab from cast-in-situ floor systemwith one-way cylindrical cavity", Journal of Building Structures, vol. 26, no. 5, pp. 53-59, 2005. (In Chinese)

[6] P-S. Shen and Z-F. Liu, "Test and Limit Load of Reinfored Concrete Waffle Slab Supported by Corner Columns of Panels", Journal of Engineering Mechanics, vol. 20, no. 4, pp. 199-203, 2003.
[7] Y. Weijun, Z. Zhenhao and M. Gaobo. "Contrast test study on reinforced concrete honeycombed-core floor and reinforced concrete multi-ribbed floor". Building Structure, vol. 40, no.4, pp. 107-110, 2010. (In Chinese)

[8] W-J. Yang, Y-H. Jiang and B. Han, Experimental Study on Honeycombed-core Reinforced Concrete Hollow Floor with Four Edges Simply Supported. In: Proceedings of the Ninth International Symposium on Structural Engineering for Young Experts, 2006.

(C) Yang et al.; Licensee Bentham Open.

This is an open access article licensed under the terms of the Creative Commons Attribution Non-Commercial License (http://creativecommons.org/lic-enses/by-nc/3.0/) which permits unrestricted, non-commercial use, distribution and reproduction in any medium, provided the work is properly cited. 